\title{
Malaria and Lyme disease - the largest vector-borne US epidemics in the last 100 years: success and failure of public health
}

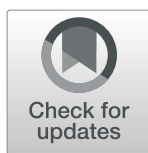

Ilia Rochlin ${ }^{1 *}$ (D, Dominick V. Ninivaggi ${ }^{2}$ and Jorge L. Benach ${ }^{3}$

\begin{abstract}
Malaria and Lyme disease were the largest vector-borne epidemics in recent US history. Malaria, a mosquito-borne disease with intense transmission, had higher morbidity and mortality, whereas Lyme and other tick-borne diseases are more persistent in the environment. The responses to these two epidemics were markedly different. The antimalaria campaign involved large-scale public works eradicating the disease within two decades. In contrast, Lyme disease control and prevention focused on the individual, advocating personal protection and backyard control, with the disease incidence steeply increasing since 1980s. Control of Lyme and other tick-borne diseases will require a paradigm shift emphasizing measures to reduce tick and host (deer) populations and a substantial R\&D effort. These steps will require changing the political climate, perceptions and opinions to generate support among governmental levels and the general public. Such support is essential for providing a real solution to one of the most intractable contemporary public health problems.
\end{abstract}

Keywords: Mosquito-borne diseases, Tick-borne diseases, Vector control, Public health history, Policy

\section{Background}

In 1897, Ronald Ross conclusively demonstrated that mosquitoes were not just a "nuisance", but vectors transmitting the deadly malaria parasite. Walter Reed's discovery that another feared disease, yellow fever, was vectored by mosquitoes quickly followed. In the nineteenth century, the incidence of these two diseases and other mosquito-borne pathogens in Europe and North America was comparable to that of many tropical regions [1]; by mid-twentieth century, both were eradicated as public health concerns. While mosquito-borne diseases remain largely suppressed, tickborne diseases are rampant, comprising over $90 \%$ of all vector transmitted pathogens in the US and Europe [2-4], with Lyme disease becoming a common infection with estimated 240,000-444,000 annual infections tripling between 2004 and $2016[3,5,6]$ with much higher most recent estimates [7] The spirochete responsible for Lyme disease was described in 1982 [8]. Almost 40 years post-discovery, its incidence continues to increase, along with other tick-

\footnotetext{
* Correspondence: ilia.rochlin@gmail.com

${ }^{1}$ Center for Vector Biology, Rutgers University, 180 Jones Avenue, New Brunswick, NJ 08901, USA

Full list of author information is available at the end of the article
}

borne diseases such as ehrlichiosis, babesiosis, and anaplasmosis [3].

Why did malaria and other mosquito-borne diseases elicit effective interventions while Lyme and the other tick-borne diseases have not? We examine this question to draw lessons needed to ensure future success against one of the most challenging contemporary public health problems.

\section{Malaria and Lyme disease in the US Malaria}

The malaria parasite is transmitted between humans and Anopheles mosquito vectors. The Anopheles immature stages inhabit marshy areas, slow moving streams, and margins of still ponds or lakes [9] (Table 1). Temperate malaria transmission is characterized by large fluctuations, low infection rates, and short seasonal longevity; outbreaks occur under increased human-vector contacts. Malaria control began primarily as public works projects founded on entomological knowledge about the mosquito vector [18]. The first report of successful mosquito control appeared in 1902 [19]; the first project targeting primarily malarial mosquitoes in 1910 [14]. Both relied on habitat modifications (drainage and filling) and oiling to kill 
Table 1 Comparison of Malaria and Lyme diseases epidemics in the US

\begin{tabular}{|c|c|c|c|}
\hline & Characteristics & Malaria & Lyme Disease \\
\hline \multirow{5}{*}{$\begin{array}{l}\text { Transmission cycle } \\
\text { and biology }\end{array}$} & Vectors & Anopheles mosquitoes & Ixodes ticks \\
\hline & Reservoirs (transmission) & Humans (human to human) & Small rodents (enzootic) \\
\hline & Pathogens & Protozoa (Plasmodium spp) & Bacteria (Borrelia spp) \\
\hline & Vector longevity and pathogen persistence & Short (days - months) & Long (years) \\
\hline & Vector aggregation (habitat) & Immature (wetlands) & Adults (deer) \\
\hline \multirow[t]{4}{*}{ Geography } & Hyperendemic areas & Deep South & Northeast, upper Mid-West \\
\hline & \# states & $13[10]$ & $14[11]$ \\
\hline & \#counties & 369 (in 1945) [10] & $318[11]$ \\
\hline & Populations at highest risk & Rural & Suburban \\
\hline \multirow[t]{3}{*}{$\begin{array}{l}\text { Control and } \\
\text { prevention }\end{array}$} & $\begin{array}{l}\text { Main control and prevention } \\
\text { methods }\end{array}$ & $\begin{array}{l}\text { Habitat modification, biological, } \\
\text { insecticides }\end{array}$ & $\begin{array}{l}\text { Personal protection, backyard } \\
\text { landscaping, public education }\end{array}$ \\
\hline & Spatial scale of control efforts & Very large (state, country) & Very small (personal, backyard) \\
\hline & $\begin{array}{l}\text { Main target of preventative } \\
\text { measures }\end{array}$ & Mosquito vector & Humans \\
\hline \multirow[t]{4}{*}{$\begin{array}{l}\text { Economics and } \\
\text { organization }\end{array}$} & Dedicated control agency & $\begin{array}{l}\text { Local mosquito control district, } \\
\text { federal (WPA), private (Rockefeller } \\
\text { institute) [12] }\end{array}$ & None \\
\hline & Funding (in $2010 \$$ ) & $\begin{array}{l}\$ 58,278,544(\$ 6,315,000 \text { in } 1948, \\
3.65 \% \text { inflation) }[10]\end{array}$ & $\$ 73,620,756$ (annual average 2005-10) [13] \\
\hline & Major expenditure & $\begin{array}{l}\text { Personnel, equipment, and supplies } \\
\text { for control (> 90\%) }[10,14]\end{array}$ & Academic and clinical research (87\%) [13] \\
\hline & Jurisdiction over habitat & $\begin{array}{l}\text { State and local Public Health Laws, } \\
\text { most publically owned }\end{array}$ & Unclear, habitat mostly privately owned \\
\hline \multirow[t]{5}{*}{ Statistics and trends } & \# infections reported/[estimated] & 68,289/[278,000-695,000] in $1941[15]$ & $\begin{array}{l}36,000 /[296,000-376,000] \text { annually in } \\
2005-2010[6]\end{array}$ \\
\hline & US incidence rate & $51.8 / 100,000$ (1941) [15] & $8.3 / 100,000[11]$ \\
\hline & Incidence rates in hyperendemic areas & $100-400 / 100,000[16]$ & $10-90 / 100,000[11]$ \\
\hline & Peak mortality in the US & $>4 / 100,000$ or $\approx 5000[17]$ & Rare \\
\hline & Trends post discovery & Declining, eradicated by 1950 s & Over 3-fold increase since 1990s \\
\hline
\end{tabular}

immature mosquitoes. Although moderate success was attained, those early efforts by private individuals were unsustainable. Realizing that long-term public support was needed, J.B. Smith of New Jersey developed the novel concept of a county-based mosquito control district supported by university affiliated experimental stations [20]. In 1912, the first municipal mosquito control association was created in New Jersey, followed by other states.

The solution to malaria was seen chiefly in vector control and secondarily as the hygienic challenge of human exposure to mosquito bites. These techniques displaced quinine, which was a known prophylactic, but did not lead to actual reduction of the pathogen in the environment $[21,22]$. While drainage, ditching, and oiling remained the mainstays of malaria mosquito control, new methods were developed by the 1920s. The mosquitofish (Gambusia affinis) was identified as a very efficient predator of mosquito larvae and the backbone of biological control [12, 23]. Paris Green, the first insecticide targeting immature aquatic stages of mosquitoes, was found to be extremely effective in reducing malaria incidence [12, 21, 24]. The county commission efforts quickly brought the desired results. In New Jersey, malaria declined from a high of almost 800 cases in 1914 to being eliminated by 1925 [20]. The last reported outbreak in New York was in 1922 [25].

However, malaria persisted in the Deep South (Fig. 1) with morbidity and mortality rates as high as 5402 and 17.4 per 100,000 residents, respectively [16]. The Rockefeller Foundation's International Health Board initiated mosquito control demonstration projects in Arkansas and Mississippi in 1916-1918 resulting in $\sim 70 \%$ reduction in malaria index and $\sim 90 \%$ drop in doctor visits [24]. Encouraged by these successes, 12 southern states assumed mosquito control responsibilities by 1925 [24].

In 1933, the anti-malaria campaign was scaled-up by the federal government through the Civil Works, Works Progress Administration, and Tennessee Valley Authority [27-29]. The scope of these projects was enormous. In 1933, the year of the program's commencement in 14 southern states, $10,000 \mathrm{~km}$ of ditches were excavated 


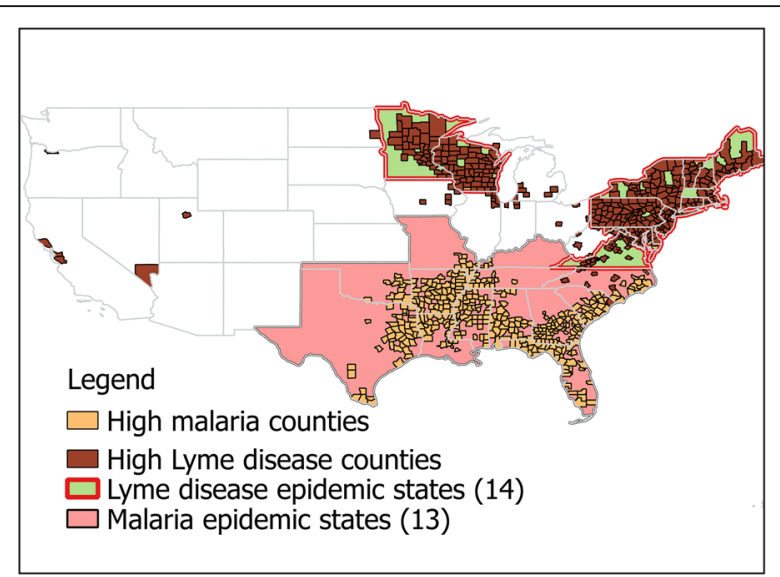

Fig. 1 Geographic distribution of hyperendemic areas of Malaria and Lyme disease in the US. Counties with high mortality and morbidity rates of malaria where the National Malaria Eradication Program was carried out in 1945-1949 [10] are in light brown. Malaria hyperendemic states are in shown in pink. High Lyme disease counties are those with $>=10$ human cases in 2016 (County level Lyme disease data [26] excluding $\mathrm{FL}$ ) in dark brown; the hyperendemic states are in green. The map was created by the authors using QGIS open source software. The administrative country level data were obtained from DIVA-GIS free spatial data depository (www.diva-gis.org)

draining 120,000 ha and affecting 8 million people [28]. Eventually, about $50,000 \mathrm{~km}$ of drainage ditches were created [30]. The 1949 report cited creating 325 reservoirs "to build malaria out", conducting work over 2.2 million ha affecting 3 million people [10]. These interventions led to steep declines in malaria morbidity from the high of about 150 to 30 , and mortality from 45 to 3 (all per 100, 000) between the mid-1930s and 1945 [17]. A survey of school aged children found $5.8 \%$ positive for malaria in 1932 compared to $0.21 \%$ in 1942 [31].

The malaria transmission cycle was suppressed but not eliminated [17, 29]. The National Malaria Eradication Program initiated in 1947 was a cooperative undertaking by 13 southern states (Fig. 1), local health agencies, and the Communicable Disease Center of the U. S. Public Health Service created specifically for the purpose of eradicating malaria $[17,27]$. A new strategy of the synthetic insecticide dichlorodiphenyltrichloroethane (DDT) treatments inside residential housing was carried out starting with 245,000 units in 1945 increasing to 1,375,000 in 1948 , and eventually to $4,650,000$ houses in all 369 counties with excess malaria mortality $[10,17]$. Only a small proportion (1-3\%) of treated houses harbored Anopheles mosquitoes compared to $13-28 \%$ of untreated homes [10]. In 1949, the country was declared free of malaria and it was officially certified eradicated 2 years later [27]. As it became clear that DDT and traditional water management methods had unacceptable adverse environmental impacts, newer techniques and materials were developed. The disease was never re-established in the USA despite at least 63 mosquito transmitted malaria outbreaks with 156 cases since 1960s [32].

While malaria was eradicated from the US, another mosquito-borne pathogen, West Nile virus (WNV) has become established since its introduction to New York City in 1999 [33]. Unlike malaria, WNV is a zoonotic disease maintained by the arbovirus circulation between birds and mosquitoes. As such, WNV incidence rate is much lower compared to malaria, however, WNV is much more geographically widespread over North and South America $[33,34]$.

Control of WNV has presented several significant challenges. WNV outbreaks are unpredictable and diffuse both spatially and temporarily [34]. Action thresholds are difficult to establish, and public health officials are often faced with conflicting public demands for taking action by mosquito treatments and avoiding insecticide use. The economic cost of WNV can be very high exceeding the operational costs of the emergency aerial mosquito control by millions of dollars [35]. However, since mosquito control programs in the US are funded by local authorities [36, 37], these programs may not have the necessary resources, adequate funding, or the political will to implement the most effective actions [36]. Decentralization of vector control efforts from the national to the local level can lead to decreased capacity to deal with mosquito-borne diseases [37], resulting in marked differences in methodology, implementation, and efficacy of mosquito control even among nearby local districts [36].

\section{Lyme disease}

The reservoir for the causative agent of Lyme disease, Borrelia burgdorferi, is the white- footed mouse $[38,39]$ (see Table 1 for comparison with malaria). Other competent host species, including rodents, rabbits, and raccoons play only a minor role $[38,39]$. The blacklegged or deer tick (Ixodes scapularis), considered medically unimportant until the 1970s [40] is now recognized as the main vector of Lyme disease [41]. Ixodes scapularis has a two- year, three-host species life cycle: larvae feed on small mammals and nymphs attack a very broad range of mammalian and bird species [38]. Nymphal ticks are primarily responsible for Lyme disease transmission to humans and animals [39]. The white-footed mouse is the principal host of immature blacklegged ticks in northeastern US due to its great abundance in the tick's habitat [42]. Adult blacklegged ticks parasitize large to medium sized mammals [38]. The white-tailed deer is an essential amplifier host $[38,42]$ responsible for the blacklegged tick's high population levels, dispersal, and intensified spread in recent decades [39, 43] maintaining B. burgdorferi transmission [44-46] and increasing the risk of Lyme disease in humans [47-50]. The increase in Lyme disease and other infections 
transmitted by blacklegged ticks has paralleled the explosive growth of deer populations [51].

In 1982 the transmission of Lyme disease spirochete to humans by a tick bite was established [8]. Reported Lyme disease cases increased from about 226 in 1981, to 9908 in 1992 (when a uniform case definition was adopted [52]), to over 30,000 in 2016 [26] (Fig. 2b). The number of actual cases are estimated at approximately $300,000[6,61]$, with the reported upper limit of over 400,000 [5] or even higher estimates [7]. The average incidence rate is $8.3 / 100,000$ ranging from about 15 to $83 / 100,000$ in "high incidence" states $[11,26]$.

No large scale vector control programs have been attempted against ticks transmitting Lyme disease [53]. The Centers for Disease Control and Prevention (CDC) recommends personal protections as the best defense against Lyme disease [54] in addition to landscaping modifications and acaricide applications to individual properties [53-56]. There is very little evidence that any of these measures are effective. Backyard pesticide use reduced the number of ticks, but had no effects on human disease or human-tick encounters [62]. While use of tick repellents increased after educational intervention to about $40 \%$, no differences in exposure to ticks was detected compared to the reference group [63]. Another recommended measure, landscape modifications, did not provide any protection against Lyme disease [64].

Public education is frequently promoted as the key to successful Lyme disease prevention [54, 55, 65]. Educational intervention in a highly endemic Lyme area in Maryland improved knowledge of ticks and Lyme disease and increased use of repellents, but did not decrease exposure to tick bites [63] . This general conclusion has been supported by numerous studies [66-68]. Even the most intensive interventions produced mixed results, e.g. slightly decreasing the rates of self-reporting tick-borne diseases in visitors, but not residents of Nantucket island [69].

These failures of public education to prevent vectorborne diseases agrees with other examples of targeted educational and personal protections interventions, such as elite military personnel acquiring malaria with extremely high incidence rates after short deployments overseas [70, 71]. Failure of these personal protection methods in highly endemic areas is theoretically expected based on modelling [72]. A prerequisite for success is lowering tick population numbers or pathogen prevalence area-wide. The only available area-wide control options to reduce tick populations target hosts for either adult (deer) or the immature (whitefooted mice) ticks [73].

Deer populations can be culled directly, or deer can be treated with topical pesticides to kill ticks. Deer population reduction was proposed as the cornerstone of integrated tick management [74]. Drastic reductions or eliminations of deer on islands were accompanied by gradual but largely significant declines in tick populations $[45,75]$. Partial deer culls resulted in smaller reductions in tick abundance [47, 76-79]. Significant reductions in tick density and Lyme disease requires very steep deer population changes to empirically estimated $3-5 / \mathrm{km}^{2}$ densities $[74,80]$. However, these studies leave many open questions with no definitive answer on the link between the reduction in deer populations and human disease.

The topical treatment of deer with pesticides using 4poster devices resulted in the overall tick reductions of $60-70 \%$ [81]. These results were highly variable. Nymphal ticks were always present at the 4-poster study treated areas [81]. Failures of the 4-poster to control tick populations have also been documented [82]. There is some evidence that 4-poster application reduced the rate of tick exposure in treatment areas by approximately threefold, which, however, remained high at erythrema migrants incidence of 137.8/100,000 [79].

Likewise, targeting white-footed mice has a mixed record. Tubes with pesticide-treated nest material generally reduced or eliminated immature ticks parasitizing mice [83], but had no effect the density of questing ticks or their infection rates $[84,85]$. Mice bait stations that incorporated pesticide applications reduced the questing tick populations [86]. It is unclear whether these methods provided any human health protection since no human health data were collected.

The rapid rise of Lyme and other tick-borne diseases has occurred despite significant investments by the federal government (Table 1 for comparison with malaria). Between 2006 and 2009, over \$100 million dollars on average were spent on tick-borne diseases annually [13]. Over 95\% were invested in the academia for microbiological and clinical research supporting the view that research of tickborne diseases became reductionist, dominated by molecular biology [87]. Vector control and entomological aspects of Lyme disease were largely relegated from the federal public health agencies to the US Department of Agriculture (USDA) [88]. Although much is known about Lyme disease, no clear prescription for prevention has emerged, and the relation of field studies to public health is unknown today, as it was 20 years ago [65].

\section{Success and failure in vector-borne disease control}

The decline of the disease in the human population is the most significant indicator of a public health program's success. The US anti-malaria campaign was thus tremendously successful, while anti-Lyme efforts are failing (Fig. 2a, b). Malaria consistently declined in 19201948 with 50\% morbidity reduction every 5 years excepting the Great Depression [17, 28] led by the hyperendemic areas (Fig. 1), where the number of high mortality counties declined from 96 to 14 between 1935 and 1942 [31]. In contrast, the Healthy People 2010 modest goal 

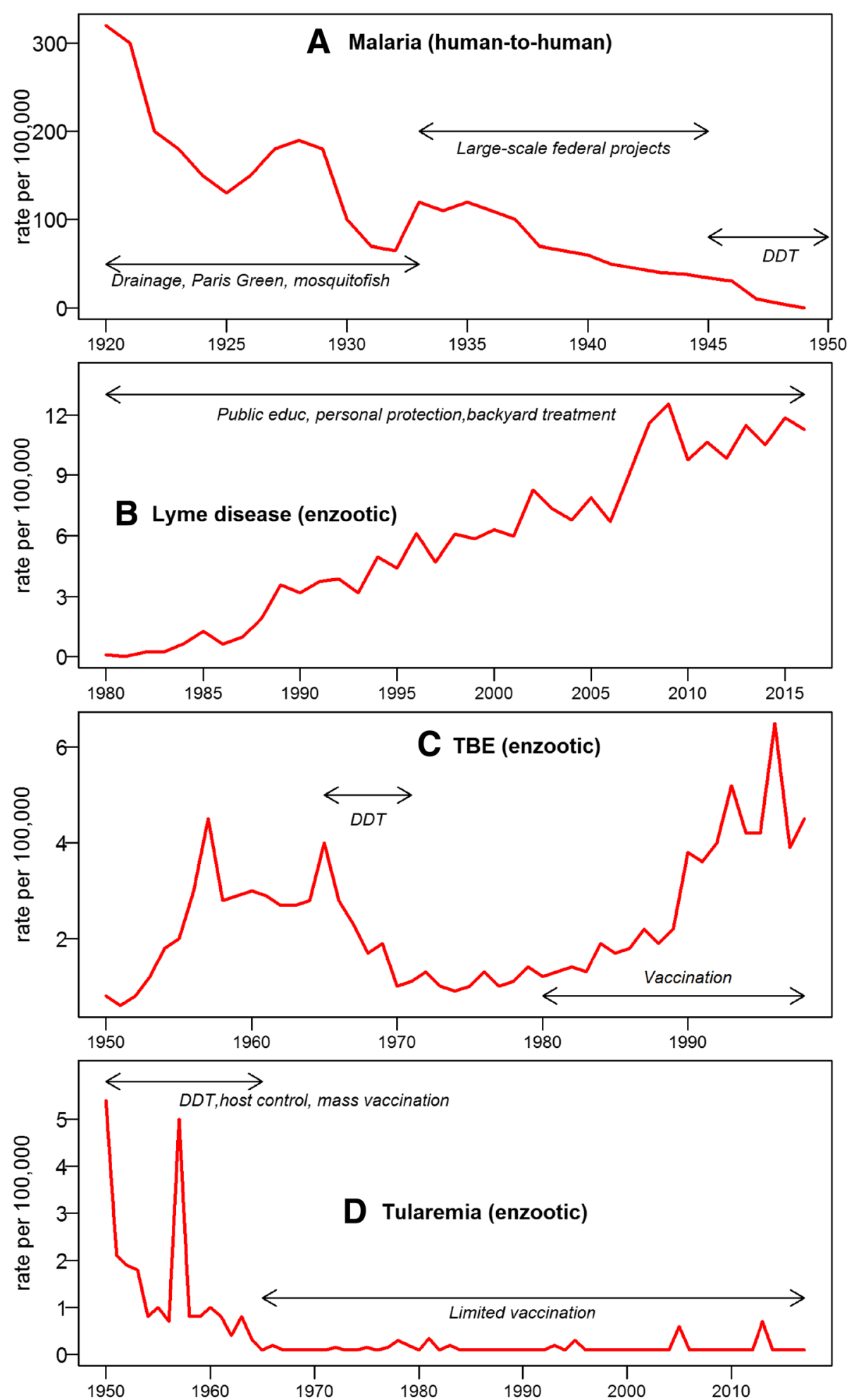

Fig. 2 (See legend on next page.) 


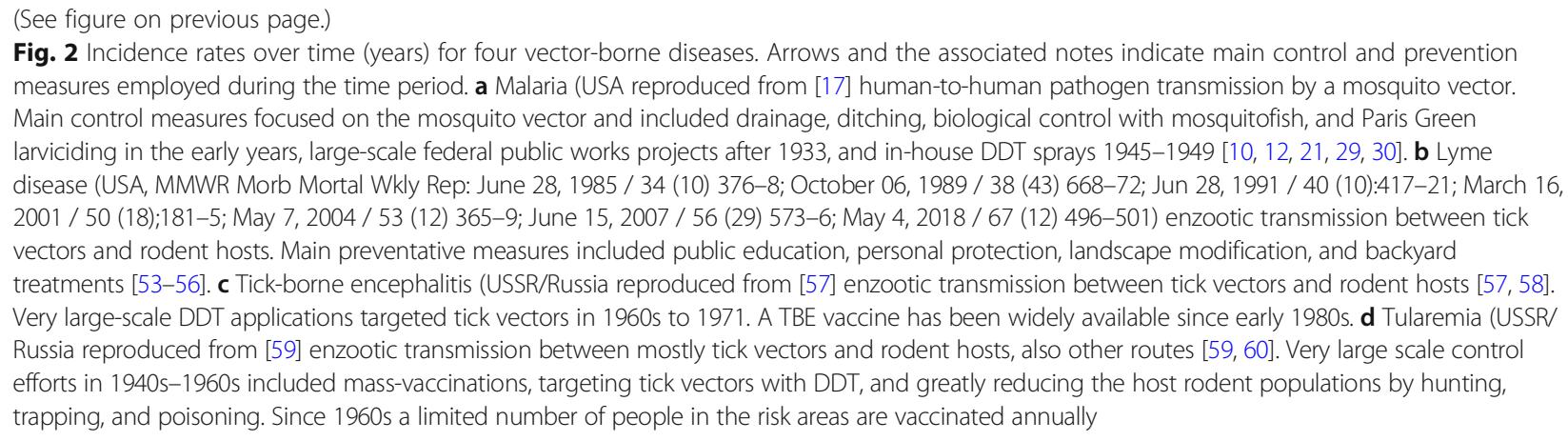

of $50 \%$ reduction in Lyme diseases incidence from 17.4 to 9.7 per $100,000[65,89]$ was not met; instead the incidence had increased threefold.

The underlying biological, technical, and societal causes for these two very different outcomes are complex. Epidemiologically, human to human transmission is more easily interrupted because both the hosts and the vector populations can be targeted to drive the basic reproductive rate $\left(R_{0}\right)$ below the rate of replacement. For malaria, vector control reduced the number of the pathogen carriers; at the same time, sanitary measures lessened the susceptible human population [90]. Targeting wildlife hosts is much more difficult proposition, which explains why pathogens with wildlife reservoirs continue to persist. This challenge is shared between all zoonotic diseases regardless of vector identity. One of the more well-known examples is West Nile virus, a mosquito-borne zoonotic disease, which remains difficult to control because its wildlife hosts are widely distributed in the environment, and virus amplification is governed by many stochastic processes [33, 34].

Biologically, the difference between mosquitoes and ticks as vectors is important [91]. Daily survival probability is very low for mosquitoes and is high for ticks translating into low population stability but higher transmission potential for mosquitoes compared to an enduring reservoir for infection but lower transmission for ticks [91]. Consequently, tick-borne diseases tend to have lower incidence rates compared to mosquito-borne diseases (Fig. 2). Adult mosquito mobility and intense feeding by immature mosquitoes make them more susceptible to dispersed or ingested insecticides. Aggregated aquatic mosquito stages are easier to target. Ticks inhabit much more cryptic environments, are spread over the suitable habitat, and have only one bloodmeal per each life stage $[39,91]$. Tick exposure is mostly peridomestic rather than recreational in the endemic areas of the United States [92, 93]. While recreational exposure on mostly public lands can be more easily mitigated by landscape modification, application of pesticides, and host management [73], residential exposure is more difficult to alleviate due to lack of access, required permissions, highly fragmented habitat, and regulatory impediments.

From the technical perspective, mosquito control was a mature science-based approach with effective techniques and products by the 1930s. Mosquito control personnel could apply chemical larvicides, use predatory killifish for biological control, or make the habitat inhospitable by drainage. No comparably effective tick products or techniques exist and the current methods of targeting the host species and habitat modification have much less impact on the tick populations.

Nevertheless, these challenges cannot fully explain the failure of public health programs since there are historical examples of successful tick-borne disease control. The most instructive cases of tick-borne encephalitis (TBE) and tularemia come from the former Soviet Union (Fig. 2c, d). The anti-TBE campaign focused chiefly on its vector, Ixodes persulcatus using DDT applications [58, 94]. The peak of the campaign in 1965-1971 was accompanied by sharp declines in TBE incidence [57] (Fig. 2c). With the cessation of DDT applications in the early 1970s, the incidence of TBE steadily increased remarkably similar to the DDT impact on mosquito populations in North America [95]. The manifold increase in TBE cases in the former Soviet Union and Europe occurred despite existence of highly effective TBE vaccines [96, 97]. Austria, where $85 \%$ of the population was vaccinated, was the only country experiencing TBE incidence decline [97]. However, relying solely on a vaccine does not work well in multi-pathogen multi-vector systems [58], and Austria has one of the highest Lyme disease burdens in the world $[2,4]$.

Arguably, the only long-term success story against a tick-borne disease is tularemia (Fig. 2d) [59, 60]. The enzootic cycle was suppressed by host removal, tick vectors were targeted by DDT applications over vast areas, strict sanitary procedures were implemented, and human protection was conferred by an effective vaccine administered on a mass-scale [60]. As a result of this integrated pest management (IPM) approach tularemia cases fell from a high of approximately 150,000 annually [98] to a 
few hundred in 1945-1959 stabilizing at $<0.5 / 100,000$ in 1965 (compared to 5.5. in 1950) and maintained by minimal vaccination in the disease hotspots [59]. The effect of DDT was strong in reducing disease incidence, but the resilience of the system seemed to depend on other factors, such as vaccination rate and host removal. More widespread distribution of Lyme disease may present more substantial challenges for these methods.

These examples bring us to the most crucial aspect of vector-borne disease control - the societal dimension political, administrative, financial, and legal. The importance of socioeconomic changes for the fight against malaria is well documented $[99,100]$. In 1943, the National Malaria Society presidential address stated "there is much to learn about malaria, we already have more information than we are using to control the disease...the main obstacles in the way of malaria control today are not so much technical, as they are social" [101], i.e. absence of educated public opinion, inadequate administrative principles, and minimal transfer of knowledge between research and applied control, all of which are valid today.

In the realm of public opinion, Lyme advocacy groups continue to drive public attention toward clinical aspects of the disease and the chronic Lyme controversies [102]. The general public would be hard pressed to find any information on vector control or other real long-term solutions to this problem. Very often novel proposals of dubious nature (such as transgenic mice or ticks) take the front stage, while very little attention is paid to developing public support for the large-scale interventions that will eventually be required to lessen the burden of tick-borne illness.

The same despondent attitude seems to prevail in public health professional organizations. The CDC, a federal agency that was created to fight malaria, doesn't even have a dedicated tick-borne disease branch despite the fact that the Lyme epidemic is becoming comparable to malaria, at least in the geographic extent if not intensity (Fig. 1). It is hard to envision the public health authorities in the 1930s promoting personal protection as the only way of eliminating malaria. Yet, the organizations tasked with public health protection nowadays do not hesitate to shift the burden to individuals and homeowners. The outcomes are clear when the long-term epidemiological data are compared: while malaria disappeared completely within two decades of vigorous efforts, Lyme disease has been on the rise over the last 40 years (Fig. 2a, b).

The repeatedly heard argument about the lack of resources for tick-borne diseases is refuted by The National Academy reporting funding levels comparable to those during the malaria eradication program (Table 1) [13]. However, 95\% out of approximately $\$ 100$ million annual appropriations are spent on fundamental molecular and clinical research. This imbalance greatly impedes the efforts to find effective control options for tick-borne diseases
[87]. These major investments have failed to produce a single useful product for tick control, host management, or a marketable vaccine. The only significant advancement in tick control of the past 40 years, the 4-poster system, was entirely supported by USDA grant [103], and not by the agencies with direct responsibility to protect public health. Contrast this with malaria, where the federal government was directing anti-malaria efforts, providing professional support, labor, development, and eventually delivering a new synthetic insecticide (DDT) to finish the job, with main resources directed toward actual vector control.

Collaboration between the federal government, academia, and local public health agencies on Lyme disease control is very limited in stark contrast to anti-malaria operations staffed, funded, and trained by the US Public Health Service and Rockefeller Foundation [12, 14, 17, 24, 104]. US Public Health scientists were not only conducting surveillance and research studies, but spent a considerable amount of their time supervising fieldwork [14]. Three federal public health stations engaging in applied research and surveillance were established in the hardest hit areas [105]. None of this federal infrastructure has been put in place during the 40 years of the current tick-borne disease epidemic.

In the early part of the twentieth century, environmental protection was not of political concern. Modern tick control methods must not only work, but be environmentally compatible. Tick control has a strong relationship with wildlife management and a new level of interactions with agencies and stakeholders unfamiliar to health authorities. The Lyme disease epidemic is so closely tied to deer overpopulation that control measures will require actively managing and reducing deer populations, at least in heavily populated areas [74].

Realization that control of the vector was essential to anti-malaria efforts engendered the political will and public policies enabling an integrated program of environmental management aimed at that vector to proceed. To emulate this success, the public health agencies, the political system and the public must come to a similar evolution in public policy. First, there must be a realization that tick-borne diseases cannot be controlled without reductions in vector populations. The relationship between ticks and deer must be recognized as the key factor in designing control efforts. At that point, all the involved agencies and stakeholders must come to accept that deer overpopulation must be part of an integrated solution. This becomes even more important as exotic tick species that feed on deer, such as the Asian longhorned tick, are introduced in the US [106]. Research and development (R\&D) efforts can then most profitably be directed at innovative methods for reducing deer populations and controlling ticks on deer, where they are most concentrated and vulnerable. This change 
in paradigm to allow effective control of tick-borne diseases will require strong leadership, especially on the Federal and State levels. Potential steps to improve the coordination among the different levels of government have been outlined [37], with the key component of increasing resources and capacities at the local level where practical vector control is carried out. While changing attitudes and policies with respect to the management of tick and deer populations will take considerable time, it will never happen if not attempted. Meanwhile, $R \& D$ funds for tick control need to be greatly increased to reflect the level of threat that exists. The most important change, however, will have to be in the "hearts and minds" of our public health and environmental managers that Lyme and other tick-borne diseases are a problem that demands serious, rationally designed largescale control measures based on cooperation of all involved parties and significant support by the federal government.

\section{Conclusions}

- Lyme epidemic is comparable to malaria in geographic extent (Fig. 1)

- Lyme epidemic intensity is lower than that of malaria mainly because of its tick vector (Table 1)

- However, Lyme disease incidence is constantly on the rise, while malaria started declining soon after the first targeted intervention in 1910 followed by complete eradication 40 years later (Fig. 2a, b)

- The ecology of Lyme disease, enzootic maintenance, and dispersed tick vectors, contribute to more challenging control compared to malaria with human to human transmission and more concentrated mosquito vectors

- In today's world, interventions that are controversial or are perceived to have adverse impacts can be successfully opposed, even by relatively small interest groups

- Because Lyme disease is almost never fatal, while there was considerable malaria mortality, the approaches to control these two diseases have been markedly different:

- Malaria - larger scale interventions, same as the scale of the epidemic covering millions of acres and millions of people; long-term prevention is carried out by local mosquito control districts - Lyme - a "needle prick" small scale approach, personal protection, public education, backyard treatments

- The funding for both epidemics is very similar; however, while the vast majority of malaria funds went for actual control and prevention, the majority of Lyme funds are allocated to academic and clinical research

- There are no historical examples of small scale interventions that successfully controlled a vectorborne or a tick-borne disease

- The successful campaigns against two tick-borne zoonotic diseases (tularemia and TBE, Fig. 2c, d) in the former Soviet Union involved multi-year largescale sustained measures against vectors and host, and mass-vaccinations

- Based on these examples, success against Lyme epidemic can only be achieved by changing the paradigm:

- Large-scale (over the entire epidemic area) and long-term (decades) interventions led by federal and state governments that include measures to reduce populations of vector ticks. It should be noted that tick control would not only reduce the incidence of Lyme disease, but also the incidence of other tick-borne pathogens

- The development of more effective, environmentally sound tick control techniques that can be implemented on a wide scale. This will require a substantial $R \& D$ effort

- Integrated approach of area-wide tick control must be accompanied by very significant deer population reduction and subsequent maintenance at epidemiologically and ecologically acceptable levels - Vaccinations (humans as well as wildlife as a novel method)

- Sustained long-term fully funded maintenance efforts by empowering the existing entities such as the mosquito control districts, or by creating new administrative structures such as state authorities

- These measures will require changing the political climate, public perceptions and opinions to generate the required public support

\section{Abbreviations}

CDC: Centers for Disease Control and Prevention;

DDT: Dichlorodiphenyltrichloroethane (synthetic insecticide); IPM: Integrated pest management; R\&D: Research and development; TBE: Tick-borne encephalitis; USDA: United States Department of Agriculture; WNV: West Nile virus

\section{Acknowledgements}

We thank E. I. Korenberg and I. Uspensky for making available copies of their articles.

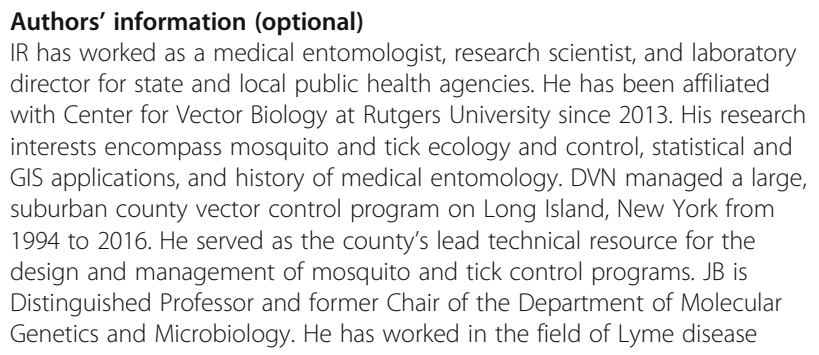


research since he participated in the discovery of its agent, Borrelia burgdorferi, in 1982. JB is a fellow of the Infectious Diseases Society of America, the American Academy of Microbiology and of the American Association for the Advancement of Science.

\section{Authors' contributions}

$I R$, DVN, and JB designed the study and wrote the manuscript. All authors have seen and approved the manuscript.

\section{Funding}

This study was supported in part by $\mathrm{NIH}$ grant $\mathrm{Al}-027044-27$ to J.B. The opinions expressed by authors contributing to this journal do not necessarily reflect the opinions of the institutions with which the authors are affiliated or the funding agencies.

\section{Availability of data and materials}

All data generated or analyzed during this study are included in this published article.

\section{Ethics approval and consent to participate}

Not applicable.

\section{Consent for publication}

Not applicable.

\section{Competing interests}

The authors declare that they have no competing interests.

\section{Author details}

${ }^{1}$ Center for Vector Biology, Rutgers University, 180 Jones Avenue, New Brunswick, NJ 08901, USA. ${ }^{2}$ Wetlands and Vector Management, LLC, 22 Rolling Hills Drive, Nesconset, NY 11767, USA. ${ }^{3}$ Department of Molecular Genetics and Microbiology, Stony Brook University, Stony Brook, NY 11794, USA.

\section{Received: 12 February 2019 Accepted: 29 May 2019}

Published online: 24 June 2019

\section{References}

1. Hong SC. The burden of early exposure to malaria in the United States, 18501860: malnutrition and immune disorders. J Econ Hist. 2007;67(4):1001-35.

2. Sykes RA, Makiello P. An estimate of Lyme borreliosis incidence in Western Europe. J Public Health (Bangkok). 2016:39(1):74-81.

3. Rosenberg R, Lindsey NP, Fischer M, Gregory CJ, Hinckley AF, Mead PS, et al. Vital Signs: Trends in Reported Vectorborne Disease Cases — United States and Territories, 2004-2016. MMWR Morb Mortal Wkly Rep. 2018;67(17):496-501.

4. Lindgren $E_{1}$ Jaenson TGT. Lyme borreliosis in Europe: influences of climate and climate change, epidemiology, ecology and adaptation measures. WHO Reg Off Eur. 2006; Available from: http://www.euro.who.int/_data/assets/ pdf_file/0006/96819/E89522.pdf?ua=1

5. Hinckley AF, Connally NP, Meek Jl, Johnson BJ, Kemperman MM, Feldman $\mathrm{KA}$, et al. Lyme Disease Testing by Large Commercial Laboratories in the United States. Clin Infect Dis. 2014;59(5):676-81.

6. Nelson CA, Saha S, Kugeler KJ, Delorey MJ, Shankar MB, Hinckley AF, et al. Incidence of Clinician-Diagnosed Lyme Disease, United States, 2005-2010. Emerg Infect Dis. 2015;21(9):1625-31.

7. Davidsson M. The Financial Implications of a Well-Hidden and Ignored Chronic Lyme Disease Pandemic. Healthcare. 2018:6(1):16.

8. Burgdorfer W, Barbour AG, Hayes SF, Benach JL, Grunwaldt E, Davis JP. Lyme disease-a tick-borne spirochetosis? Science (80- ). 1982;216(4552):1317-9.

9. Foster WA, Walker ED. Mosquitoes (Culicidae). In: Mullen G, Durden L, editors. Med Vet Entomol; 2002. p. 203-62.

10. Bradley GH, Lyman EF. Recent Developments in the Anti-Mosquito Work of the Communicable Disease Center U. S. Public Health Service. Proceeding New Jersey Mosq Control Assoc. 1949;36:68-74.

11. Schwartz AM, Hinckley AF, Mead PS, Hook SA, Kugeler KJ. Surveillance for Lyme Disease - United States, 2008-2015. Morb Mortal Wkly Rep Surveill Summ. 2017:66(22):1-12.

12. Rockefeller Foundation. Malaria Control Program, Yazoo County, Mississipp [Internet]. 1923. Available from: https://rockfound.rockarch.org/digital-library-
listing/-/asset_publisher/yYxpQfel4W8N/content/malaria-control-programyazoo-county-mississippi

13. NIH. Federal Funding of Tick-Borne Diseases [Internet]. Critical Needs and Gaps in Understanding Prevention, Amelioration, and Resolution of Lyme and Other Tick-Borne Diseases: The Short-Term and Long-Term Outcomes: Workshop Report. US: National Academies Press; 2011. [cited 2018 Jul 31]. Available from: https://www.ncbi.n/m.nih.gov/books/NBK57017/

14. Bradley GH. The Entomological Phases of Malaria Control Programs. J Natl Malar Soc. 1944;3(4):249-53.

15. Faust EC. Malaria Mortality and Morbidity in the United States for the Year 1941. J Natl Malar Soc. 1943:2(1):39-46.

16. Kitchens $C$. The effects of the Works Progress Administration's anti-malaria programs in Georgia 1932-1947. Explor Econ Hist. 2013;50(4):567-81.

17. Andrews JM, Gilbertson WE. Final Phases of Malaria Eradication in the United States. J Natl Malar Soc. 1950;9(1):5-9.

18. Felt EP. Mosquitos or Culicidae of New York State. New York State Museum Bull. 1904:79.

19. Shaler NS. Reports on Plans for the Extermination of Mosquitoes on the North Shore of Long Island Between Hempstead Harbor and Cold Spring Harbor. Press of Styles \& Cash. 1902.

20. NJAES. The Story of the Mosquito. New Jersey Agricultural Experiment Station; 1946. 31 pp. (Circular; vol. 502).

21. Stapleton DH. Lessons of history? Anti-malaria strategies of the International Health Board and the Rockefeller Foundation from the 1920s to the era of DDT. Public Health Rep. 2004;119(2):206-15.

22. Faust EC. The history of malaria in the United States, vol. 39: American Scientist; 1951. p. 121-30.

23. Hildebrand SF. A Study of the Top Minnow, Gambusia holbrooki, in its Relation to Mosquito Control. Public Health Bulletin (Wash D C). 1925;(153).

24. Rockefeller Foundation Reports. Annual Reports - The Rockefeller Foundation 1914- [Internet]. [cited 2018 Jul 31]. Available from: https://www. rockefellerfoundation.org/about-us/governance-reports/annual-reports/

25. Means RG. Mosquitoes of New York. Part II. Genera of Culicidae other than Aedes occurring in New York. New York State MusBull430b. 1987;

26. CDC. Lyme disease data and statistics [Internet]. 2018 [cited 2018 Jul 31]. Available from: https://www.cdc.gov/lyme/stats/index.html

27. CDC, Centres for Disease Control and Prevention. The History of Malaria, an Ancient Disease [Internet]. Public Health. 2016. Available from: https://www. cdc.gov/malaria/about/history/index.html

28. Williams LL Jr. Civil Works Administration Emergency Relief Administration Malaria Control Program in the South. Am J Public Health Nations Health. 1935;25(1):11-4.

29. Sledge D, Mohler G. Eliminating Malaria in the American South: An Analysis of the Decline of Malaria in 1930s Alabama. Am J Public Health. 2013;103(8):1381-92.

30. Andrews JM. What's Happening to Malaria in the USA? Am J Public Health Nations Health. 1948;38(7):931-42.

31. Mountin JW. A program for the eradication of malaria from continental United States. J Nat Malar Soc. 1944;3:69-73.

32. Filler SJ, MacArthur JR, Parise M, Wirtz R, Eliades MJ, Dasilva A, et al. Locally acquired mosquito-transmitted malaria: a guide for investigations in the United States. MMWR Recomm reports Morb Mortal Wkly Rep. 2006;55(RR-13:1-9.

33. Kramer LD, Styer LM, Ebel GD. A global perspective on the epidemiology of West Nile virus. Annu Rev Entomol. 2008:53:61-81.

34. Petersen LR, Fischer M. Unpredictable and Difficult to Control — The Adolescence of West Nile Virus. N Engl J Med. 2012;367(14):1281-4.

35. Barber LM, Schleier JJ, Peterson RKD. Economic Cost Analysis of West Nile Virus Outbreak, Sacramento County, California, USA, 2005. Emerg Infect Dis. 2010;16(3):480-6.

36. Tedesco C, Ruiz M, McLafferty S. Mosquito politics: Local vector control policies and the spread of West Nile Virus in the Chicago region. Health Place. 2010;16(6):1188-95.

37. Petersen $L R$, Beard $C B$, Visser SN. Perspective Piece Combatting the Increasing Threat of Vector-Borne Disease in the United States with a National Vector-Borne Disease Prevention and Control System. Am J Trop Med Hyg. 2019;100(2):242-5.

38. Anderson JF. Ecology of Lyme disease. Conn Med. 1989:53(6):343-6.

39. Sonenshine DE. Biology of Ticks. Vol. Volume 2. New York: Oxford University Press, Inc; 1993.

40. Jamnback H. Bloodsucking flies and other outdoor nuisance arthropods of New York State. The State Education Department, Albany, NY: State Museum and Science Service; 1969. 
41. Piesman J, Gray JS. In: Mather STN, editor. Lyme disease/Lyme borreliosis. Ecol Dyn tick-borne zoonoses. New York: Oxford Univ Press Inc; 1994. p. 327-50.

42. Piesman J, Spielman A, Etkind P, Ruebush TK, Juranek DD. Role of deer in the epizootiology of Babesia microti in Massachusetts, USA. J Med Entomol. 1979;15(5-6):537-40

43. Sonenshine DE, Mather TN. Ecological dynamics of tick-borne zoonoses: Oxford University Press; 1994.

44. Barbour AG, Fish D. The biological and social phenomenon of Lyme disease. Science. 1993;260(5114):1610-6.

45. Wilson ML, Telford SR, Piesman J, Spielman A. Reduced Abundance of Immature Ixodes dammini (Acari: Ixodidae) Following Elimination of Deer. J Med Entomol. 1988;25(4):224-8.

46. Lane RS, Piesman J, Burgdorfer W. Lyme Borreliosis: Relation of Its Causative Agent to Its Vectors and Hosts in North America and Europe. Annu Rev Entomol. 1991;36(1):587-609.

47. Kilpatrick HJ, Labonte AM, Stafford KC. The Relationship Between Deer Density, Tick Abundance, and Human Cases of Lyme Disease in a Residential Community. J Med Entomol. 2014;51(4):777-84.

48. Raizman EA, Holland JD, Shukle JT. White-Tailed Deer (Odocoileus virginianus ) as a Potential Sentinel for Human Lyme Disease in Indiana. Zoonoses Public Health. 2013;60(3):227-33.

49. Werden L, Barker IK, Bowman J, Gonzales EK, Leighton PA, Lindsay LR, et al. Geography, Deer, and Host Biodiversity Shape the Pattern of Lyme Disease Emergence in the Thousand Islands Archipelago of Ontario, Canada. PLoS One. 2014;9(1):e85640.

50. Wilson ML, Ducey AM, Litwin TS, Gavin TA, Spielman A. Microgeographic distribution of immature Ixodes dammini ticks correlated with that of deer. Med Vet Entomol. 1990:4(2):151-9.

51. Barbour AG. Fall and rise of Lyme disease and other ixodes tick-borne infections in North America and Europe. Br Med Bull. 1998.

52. Bacon R, Kugeler K, Mead P. Surveillance for Lyme disease--United States, 1992-2006. Morb Mortal Wkly Rep Surveill Summ. 2008;57(10):1-9.

53. Ginsberg HS, Stafford IIIKC. Management of ticks and tick-borne diseases. In: Goodman JL, Dennis DT, Sonenshine DE, editors. Tick-borne diseases of humans. Washington, D.C.: American Society for Microbiology; 2005. p. 65-86.

54. Beard CB, Strickman D. Federal initiative: tick-borne disease integrated pest management white paper [Internet]. https:/wwww.epa.gov/sites/production/files/ 2016-02/documents/tick-ipm-whitepaper.pdf. Washington, DC: Federal Tick-Borne Disease Integrated Pest Management Workgroup; 2014. Available from: https:/ unw.epa.gov/sites/production/files/2016-02/documents/tick-ipm-whitepaper.pdf

55. Clark RP, Hu LT. Prevention of Lyme Disease and Other Tick-Borne Infections. Infect Dis Clin North Am. 2008:22(3):381-96.

56. Hook SA, Nelson CA, Mead PS. U.S. public's experience with ticks and tickborne diseases: Results from national HealthStyles surveys. Ticks Tick Borne Dis. 2015;6(1877-9603):483-8.

57. Korenberg El, Kovalevskii YV. Main features of tick-borne encephalitis ecoepidemiology in Russia. Zentralblatt für Bakteriol. 1999;289(5-7):525-39.

58. Uspensky I. Ticks as the main target of human tick-borne disease control: Russian practical experience and its lessons. J Vector Ecol. 1999;24(1):40-53.

59. Kudryavtseva TY, Popov VP, Mokrievich AN, Pakskina ND, Kholin AV, Mazepa AV, et al. Tularemia: Relevant Issues and Forecast of Epidemic Situation in the Territory of the Russian Federation in 2018. Probl Osobo Opasnykh Infektsii [Problems Part Danger Infect (In Russ)]. 2018;1:22-9.

60. Pavlovsky EN. In: Levine ND, editor. Natural nidality of transmissible diseases, with special reference to the landscape epidemiology of zooanthroponoses. Urbana, IL: Urbana (\& London): University of Illinois Press; 1966.

61. CDC. Estimate of Americans diagnosed with Lyme disease each year [Internet]. 2013. Available from: https://www.cdc.gov/media/releases/2013/ p0819-lyme-disease.html

62. Hinckley AF, Meek Jl, Ray JAE, Niesobecki SA, Connally NP, Feldman KA, et al. Effectiveness of Residential Acaricides to Prevent Lyme and Other Tickborne Diseases in Humans. J Infect Dis. 2016;214(2):182-8.

63. Malouin $R$, Winch $P$, Leontsini E, Glass G, Simon D, Hayes EB, et al. Longitudinal Evaluation of an Educational Intervention for Preventing Tick Bites in an Area with Endemic Lyme Disease in Baltimore County, Maryland. Am J Epidemiol. 2003;157(11):1039-51.

64. Connally NP, Durante AJ, Yousey-Hindes KM, Meek Jl, Nelson RS, Heimer R. Peridomestic Lyme Disease Prevention. Results of a Population-Based CaseControl Study Am J Prev Med. 2009;37(3):201-6.

65. Poland GA. Prevention of Lyme disease: a review of the evidence. In: Mayo Clinic Proceedings: Elsevier; 2001. p. 713-24.
66. Ley C, Olshen EM, Reingold AL. Case-Control Study of Risk Factors for Incident Lyme Disease in California. Am J Epidemiol. 1995; 142(Supplement 9):S39-47.

67. Orioski KA, Campbell GL, Genese CA, Beckley JW, Schriefer ME, Spitalny KC, et al. Emergence of Lyme Disease in Hunterdon County, New Jersey, 1993 A Case-Control Study of Risk Factors and Evaluation of Reporting Patterns. Am J Epidemiol. 1998;147(4):391-7.

68. Smith PF, Benach JL, White DJ, Stroup DF, Morse DL. Occupational Risk of Lyme Disease in Endemic Areas of New York State. Ann N Y Acad Sci. 1988; 539(1 Lyme Disease):289-301.

69. Daltroy LH, Phillips C, Lew R, Wright E, Shadick NA, Liang MH, et al. A Controlled Trial of a Novel Primary Prevention Program for Lyme Disease and Other Tick-Borne IIInesses. Health Educ Behav. 2007;34(3):531-42.

70. Kotwal RS, Wenzel RB, Sterling RA, Porter WD, Jordan NN, Petruccelli BP. An outbreak of malaria in US Army Rangers returning from Afghanistan. JAMA. 2005;293(2):212-6

71. Whitman TJ, Coyne PE, Magill AJ, Blazes DL, Green MD, Milhous WK, et al. An outbreak of Plasmodium falciparum malaria in U.S. Marines deployed to Liberia. Am J Trop Med Hyg. 2010;83(2):258-65.

72. Ginsberg HS. Transmission risk of Lyme disease and implications for tick management. Am J Epidemiol. 1993;138(1):65-73.

73. Eisen RJ, Piesman J, Zielinski-Gutierrez E, Eisen L. What Do We Need to Know About Disease Ecology to Prevent Lyme Disease in the Northeastern United States. J Med Entomol. 2012;49(1):11-22.

74. Telford SR. Deer Reduction Is a Cornerstone of Integrated Deer Tick Management. J Integr Pest Manag. 2017;8(1).

75. Rand PW, Lubelczyk C, Holman MS, Lacombe EH, Smith RP. Abundance of Ixodes scapularis (Acari: Ixodidae) after the complete removal of deer from an isolated offshore island, endemic for Lyme Disease. J Med Entomol. 2004;41(4):779-84.

76. Deblinger RD, Wilson ML, Rimmer DW, Spielman A. Reduced Abundance of Immature Ixodes dammini (Acari: Ixodidae) Following Incremental Removal of Deer. J Med Entomol. 1993;30(1):144-50.

77. Jordan RA, Schulze TL, Jahn MB. Effects of Reduced Deer Density on the Abundance of Ixodes scapularis (Acari: Ixodidae) and Lyme Disease Incidence in a Northern New Jersey Endemic Area. J Med Entomol. 2007:44(5):752-7.

78. Kilpatrick HJ, LaBonte AM. Deer hunting in a residential community: the community's perspective. Wildl Soc Bull. 2003;31(2):340-8.

79. Garnett JM, Connally NP, Stafford KC, Cartter ML. Evaluation of DeerTargeted Interventions on Lyme Disease Incidence in Connecticut. Public Health Rep. 2011;126(3):446-54

80. Kugeler K, Jordan RA, Schulze TL, Griffith KS, Mead PS. Will Culling WhiteTailed Deer Prevent Lyme Disease? Zoonoses Public Health. 2016;63(5):337-45.

81. Brei B, Brownstein JS, George JE, Pound JM, Miller JA, Daniels TJ, et al. Evaluation of the United States Department of Agriculture Northeast AreaWide Tick Control Project by Meta-Analysis. Vector-Borne Zoonotic Dis. 2009;9(4):423-30.

82. Grear JS, Koethe R, Hoskins B, Hillger R, Dapsis L, Pongsiri M. The effectiveness of permethrin-treated deer stations for control of the Lyme disease vector Ixodes scapularis on Cape Cod and the islands: a five-year experiment. Parasit Vectors. 2014;7(1):292 Available from: http:// parasitesandvectors.biomedcentral.com/articles/10.1186/1756-3305-7-292. [cited 2018 Jul 31].

83. Deblinger RD, Rimmer DW. Efficacy of a Permethrin-Based Acaricide to Reduce the Abundance of Ixodes dammini (Acari: Ixodidae). J Med Entomol. 1991;28(5):708-11.

84. Daniels TJ, Fish D, Falco RC. Evaluation of Host-Targeted Acaricide for Reducing Risk of Lyme Disease in Southern New York State. J Med Entomol. 1991;28(4):537-43.

85. Stafford KC. Effectiveness of Host-Targeted Permethrin in the Control of Ixodes dammini (Acari: Ixodidae). J Med Entomol. 1991;28(5):611-7.

86. Schulze TL, Jordan RA, Williams M, Dolan MC. Evaluation of the SELECT Tick Control System (TCS), a Host-Targeted Bait Box, to Reduce Exposure to Ixodes scapularis (Acari: Ixodidae) in a Lyme Disease Endemic Area of New Jersey. J Med Entomol. 2017;54(4):1019-24.

87. Fish D. Why we do not understand the ecological connections between the environment and human health: The case for vector-borne disease [Internet]. Vector-borne Diseases: Understanding the Environmental, Human Health and Ecological Connections. Washington (DC): National Academies Press (US); 2008. 65-69 p. Available from: https://www.ncbi.nlm.nih.gov/ books/NBK52945/ 
88. Childs JE. Low tech versus high tech approaches for vector-borne disease control. Vector-Borne Zoonotic Dis. 2009;9(4):355-6.

89. Centers for Disease Control and Prevention. Healthy people 2010: Immunization and infectious diseases [Internet]. 2010. Available from: https://www.cdc.gov/nchs/data/hpdata2010/hp2010_final_review_ focus_area_14.pd

90. Smith DL, Ellis McKenzie F. Statics and dynamics of malaria infection in Anopheles mosquitoes. Malar J. 2004;3(1):13.

91. Randolph SE. Ticks are not Insects: Consequences of Contrasting Vector Biology for Transmission Potential. Parasitol Today. 1998;14(5):186-92.

92. Connally NP, Ginsberg HS, Mather TN. Assessing peridomestic entomological factors as predictors for Lyme disease. J Vector Ecol. 2006 Dec;31(2):364-70.

93. Falco RC, Fish D. Prevalence of Ixodes dammini near the homes of Lyme disease patients in Westchester County, New York. Am J Epidemiol. 1988; 127(4):826-30.

94. Uspensky I. Tick-borne encephalitis prevention through vector controi in Russia. Rev Med Vet Entomol. 1996;84(10):679-89.

95. Rochlin I, Faraji A, Ninivaggi DV, Barker CM, Kilpatrick AM. Anthropogenic impacts on mosquito populations in North America over the past century Nat Commun. 2016;7:13604.

96. Amicizia D, Domnich A, Panatto D, Lai PL, Cristina ML, Avio U, et al. Epidemiology of tick-borne encephalitis (TBE) in Europe and its prevention by available vaccines. Hum Vaccin Immunother. 2013:9(5):1163-71.

97. Heinz FX, Stiasny K, Holzmann H, Grgic-Vitek M, Kriz B, Essl A, et al. Vaccination and tick-borne encephalitis, central Europe. Emerg Infect Dis. 2013;19(1):69-76.

98. Kucheruk W. Mammals--carriers of diseases dangerous to to man. Folia Parasitol. 1975;22:145-51.

99. Humphreys M. Malaria: poverty, race, and public health in the United States, Baltimore and London: Johns Hopkins University Press; 2001.

100. Packard RM. The making of a tropical disease: a short history of malaria. Baltimore: Johns Hopkins University Press; 2007.

101. O'Neill JH. The war and our opportunity for service. J Nat Malar Soc 1943;2(1):5-13.

102. Lyme Disease Association [Internet]. Testimonies, Speeches \& Positions. 2018 [cited 2018 Jul 8]. Available from: https://www.lymediseaseassociation. org/about-us/speeches-a-positions

103. Pound JM, Miller JA, George JE, Fish D. The United States Department of Agriculture northeast area-wide tick control project: History and protocol. Vector-Borne Zoonotic Dis. 2009;9(4):365-70.

104. Freeborn SB. The malaria control program of the United States Public Health Service among civilians in extra- military areas. J Natl Malar Soc. 1944;3(1):19-23.

105. Bradley GH, Goodwin MHJ. Malaria observation stations of the Public Health Service. J Natl Malar Soc. 1949;8(3):181-91.

106. Rainey T, Occi JL, Robbins RG, Egizi A. Discovery of Haemaphysalis longicornis (Ixodida: Ixodidae) Parasitizing a Sheep in New Jersey, United States. J Med Entomol. 2018;55(3):757-9.

\section{Publisher's Note}

Springer Nature remains neutral with regard to jurisdictional claims in published maps and institutional affiliations.

Ready to submit your research? Choose BMC and benefit from:

- fast, convenient online submission

- thorough peer review by experienced researchers in your field

- rapid publication on acceptance

- support for research data, including large and complex data types

- gold Open Access which fosters wider collaboration and increased citations

- maximum visibility for your research: over $100 \mathrm{M}$ website views per year

At $\mathrm{BMC}$, research is always in progress.

Learn more biomedcentral.com/submissions 